\title{
The use of piezocone tests for high-resolution stratigraphy of Quaternary Sediment Sequences in the Brazilian coast
}

\author{
GIULIANO DE MIO ${ }^{1}$ and HERALDO L. GIACHETI ${ }^{2}$ \\ ${ }^{1}$ Departamento de Geotecnia, Universidade de São Paulo, Av. Trabalhador São Carlense, 400, Centro, 13566-590 São Carlos, SP, Brasil \\ ${ }^{2}$ Departamento de Engenharia Civil, Faculdade de Engenharia de Bauru, Universidade do Estado de São Paulo \\ Rua Luiz E.C. Coube s/n, Caixa Postal 473, 17033-360 Bauru, SP, Brasil \\ Manuscript received on May 27, 2005; accepted for publication on April 17, 2006; \\ presented by KENITIRO SUGUIO

\begin{abstract}
Correlations between mapping units of costal sedimentary basin and interpretation of piezocone test results are presented and discussed based on examples from Caravelas strandplain, (State of Bahia), Paranaguá (State of Paraná) and Guarujá bays (State of São Paulo), Brazil. Recognizing that the sedimentary environment was mainly controlled by sea level fluctuations led to the interpretation of transgressive and regressive sedimentary sequences, which is in a good agreement with the sea level fluctuation curves currently accepted for these regions. The interpretation of piezocone test results shows that the sedimentary sequences of Caravelas and Guarujá sites are similar and they have a good correlation to the sea level fluctuation curve accepted for Salvador region, State of Bahia. On the other hand, the piezocone test results from Paranaguá site indicate a different sedimentary sequence from the previous ones, relating to the sea level fluctuation curve accepted for Paranaguá region. The results show the high applicability of piezocone testing for stratigraphical logging and suggest that it is possible to integrate it with other current techniques used for paleo-environmental studies in Brazil, in accordance with recent approaches used in international research on the subject.
\end{abstract}

Key words: stratigraphic logging, piezocone test, paleoenvironment, geological mapping.

\section{INTRODUCTION}

Quaternary sediment sequences have been studied to understand past environmental changes and to support analysis of the impact of environmental conditions on the future of mankind. Quaternary sediment sequences are mainly developed on marine transitional areas, lagoons and some restricted floodplain environments. Sediment distribution and composition are strongly influenced by climatic and tectonic conditions, and can contain a diversity of fossils and prehistoric records which can support palynological, paleontological, paleoenvironmental and archeological studies.

The understanding that the Earth is a limited environment, with restricted and finite resources, has led re-

Correspondence to: Giuliano De Mio

E-mail: gdemio@golder.com.br searchers worldwide to try to understand natural changes and the influence of mankind on the environment. This kind of research uses a variety of methods, and a detailed stratigraphy of sediments could represent an important contribution to the understanding of all other studies. Amorosi and Marchi (1999), based on a detailed comparison of piezocone test data and boreholes, show that piezocone testing can be used for sedimentological purposes, including detailed facies characterization, subsurface stratigraphic correlations, and identification of the key surfaces for sequence-stratigraphic interpretation. Traditional techniques, like vibracore, produce good quality samples, but can reach only limited depths and are expensive requiring detailed description by expert technicians. Recently a new in situ testing technique used for characterization of unconsolidated sedi- 
ments, the piezocone test (CPTU), has been developed for geotechnical studies (Robertson et al. 1986). It has an automated process whereby an electronically instrumented steel probe is quasi-statically inserted into the soil, using specific machines. Piezocone test produces a continuous profile quickly visualized on a computer screen. It does not produce samples, but allows the interpretation of a detailed profiling of sediments, which can be easily interpreted for classification, identification of strata transition, and variability studies, and when combined with geological interpretation gives high resolution stratigraphy very rapidly. This technique has been tested by a variety of researchers (Amorosi and Marchi 1999, Hegazy et al. 1991, Colas et al. 2005) and the main conclusion is that piezocone can be extensively used for stratigraphic studies. It is just necessary to locally calibrate the results with a continuous profile from vibracore or another sampling technique.

In this paper, piezocone test results are compared with published paleo-stratigraphic mapping from the Caravelas region, in the state of Bahia in northern Brazil, on a coastal sedimentary sequence. Two additional piezocone test results from Paranaguá and Guarujá bays are also presented and discussed, indicating that the Paranaguá area has a particular layer sequence that differs significantly from the Guarujá and Caravelas areas (Figure 1). The sedimentary environments and layer sequences are mainly controlled by sea level fluctuations during the late Quaternary, and indicate that each area has specific characteristics, probably related to different tectonic behavior or to different sediment delivery rates. This fits well with the assumptions of Martin et al. (2003) that the general pattern of sea level on the Brazilian coast is similar among all sectors, and indicates that this coast was subjected to a submergence phase until about $5,100{ }^{14} \mathrm{C}$ yr. BP, followed until recently by a drop in sea level. This drop was interrupted by highfrequency oscillations that are clearly reflected in the sediment sequences from the Caravelas and Guarujá sites. Lessa and Angulo (1995) have argued that these highfrequency oscillations did not existed for the Paranaguá Bay region, and the sediment sequences interpreted from piezocone test results, confirm that this region has a distinct Quaternary evolutionary history. The results presented indicate a good correlation between superficial mapping units and the general characteristics identified through the interpretation of sediment sequence profiles from piezocone tests. A relationship between the sediment sequences and the sea level changes during the Quaternary period is proposed. Test data from Caravelas and Guarujá fit well with the Salvador's curve (Martin et al. 2003), show a similar pattern of layer intercalation, and represent three transgressive/regressive cycles. Test data from Paranaguá Bay indicate that the sedimentary sequence has a different transgressive/regressive pattern, and they are compared to the curve suggested by Angulo and Lessa (1997).

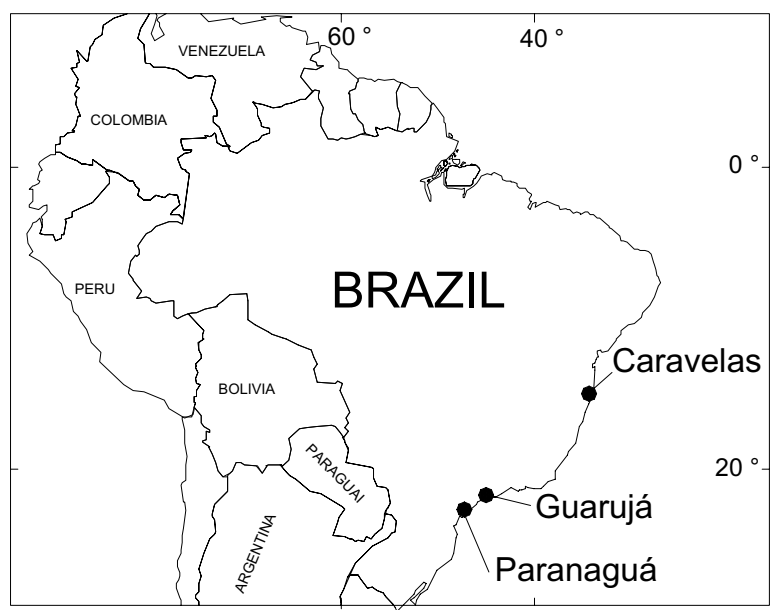

Fig. 1 - Location of the sites from where piezocone test results have been collected along the eastern Brazilian coast.

The main objectives of this paper are to show the usefulness of the piezocone for this application in the late Quaternary sediments from Brazil and to contribute to the discussion on the different sea level fluctuation patterns for the Brazilian coast. The results presented are preliminary, and future combinations of piezocone test with radiocarbon dating and bioturbation studies, currently used techniques in paleoenvironmental mapping, are recommended to extend and make more understandable the findings presented in this paper.

\section{PIEZOCONE TESTS}

Piezocone is a standard site investigation tool, currently used for geotechnical site characterization. The piezometer cone penetration test (CPTU) is a standard instrumented probe (ASTM D-3441. 1986 and ABNT MB- 
3406. 1994) with a $60^{\circ}$ apex and typically $35.7 \mathrm{~mm}$ diameter $\left(10 \mathrm{~cm}^{2}\right.$ area) on the end of a series of rods (Figure 2). The piezocone is pushed into the ground at a constant rate of $2 \mathrm{~cm} / \mathrm{sec}$ by hydraulic pushing source, such as a standard drill rig or outfitted cone pushing vehicle. As the cone is advanced, the forces measured by the tip and friction sleeve will vary with the material properties of the soil being penetrated. Tip resistance $\left(q_{c}\right)$, friction sleeve stress $\left(f_{s}\right)$, and pore pressure $(u)$ response are measured by calibrated strain gauges and pressure transducers. Temperature (t) and inclination (i) can also be measured simultaneously as the piezocone is advanced. All channels are continuously monitored and typically digitized at $10,25 \mathrm{~mm}$ or $50 \mathrm{~mm}$ intervals. Data is acquired in a computer which allows the user to carry out straightforward post-investigation analyses.

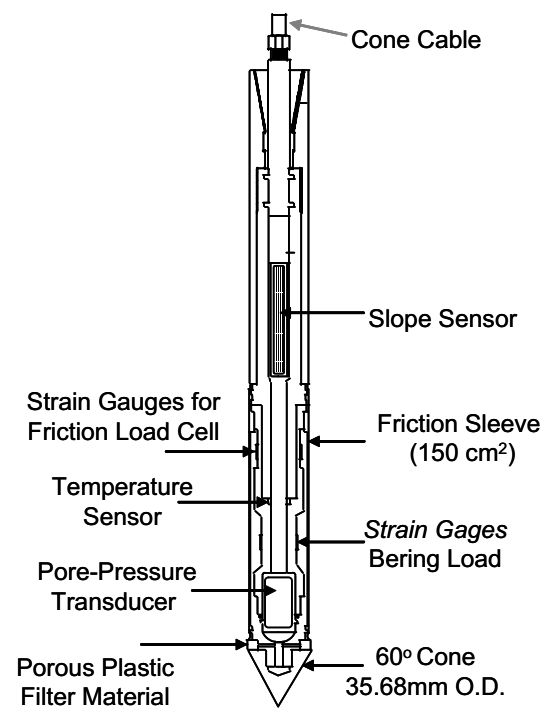

Fig. 2 - Schematic piezocone probe representation (Davies and Campanella 1995).

The standard piezocone measurements can be used as a tool for logging soils. Empirical and semi-theoretical correlations are available in the literature to estimate mechanical properties of the soils. The measurements of excess pore pressure, which are generated during penetration and their subsequent dissipation provided insight into the soil type and its hydraulics parameters. Recently, specific sensors for seismic, resistivity, $\mathrm{pH}$, laserinduced fluorescence, ground penetration radar, among others have been attached to the piezocone for a bet- ter site characterization especially for geoenvironmental applications (Lunne et al. 1997). Gravel layers and boulders, heavily cemented zones, many dense tills and very thick, dense sand layers can restrict the penetration severely and deflect or damage probes and rods, especially if overlying soils are very soft and allow rod buckling. However, in soft to medium dense soils, cone penetration to depths in excess of $100 \mathrm{~m}$ may be achieved when there is enough pushing force and verticality is maintained (Davies and Campanella 1995).

Sediment classification can be done using specific charts (Robertson et al. 1986, Fellenius and Eslami 2000), produced by correlation among $q_{c}, f_{s}$ and $u$ response and borehole samples. Most of the charts have the same structure and the classifications vary depending on different database or specific corrections like test depth or material genesis. The classification based on piezocone test results considers two basic principles. The first one is that sands have high point resistance and low lateral friction, and clays have low point resistance and high lateral friction. Considering this basic principle it was proposed the friction ratio $\left(F_{r}\right)$ that is the percentile relation between lateral friction and point resistance, as follow:

$$
F_{r}=\left(f_{s} / q_{c}\right) * 100
$$

Low friction ratios indicate sand materials and high friction ratios indicate clay materials. The second basic principle, that guides piezocone interpretation, uses the pore-pressure response during the penetration. The application of loads on saturated sediments, through the penetration of the probe, makes the pressure instantaneously be transmitted to the soil pore water. Fine grained soils, with low permeability, do not permit a quick dissipation of this pressure and the piezocone pore-pressure values $(u)$ increase. Coarse-grained sediments, with high permeability, permit the quick dissipation of excess pore pressure, and the piezocone porepressure values $(u)$ do not increase. The pore-pressure sensor measures the excesses of pressure generated by the probe penetration and the pressure produced by the water column above the investigated depth. Water pressures can act on the exposed surfaces behind the cone tip. These water forces result in measured tip resistance $\left(q_{c}\right)$ values that do not represent true total stress resis- 

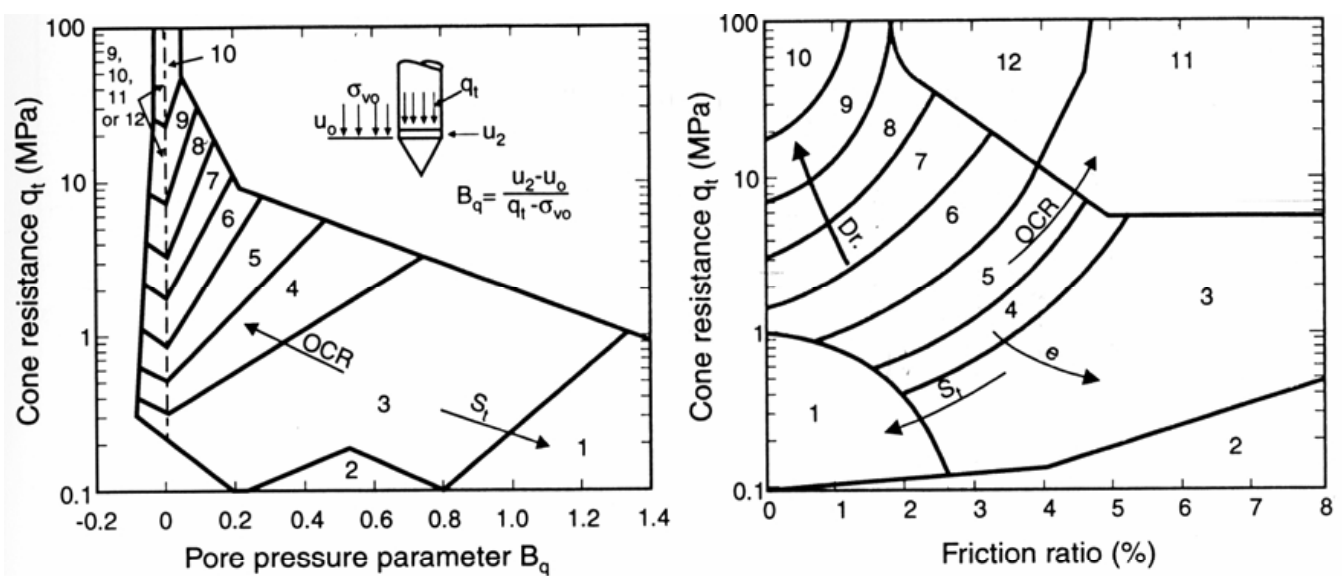

Zone: Soil Behaviour Type:

$\begin{array}{ll}\text { 1. } & \text { Sensitive fine grained } \\ \text { 2. } & \text { Organic material } \\ \text { 3. } & \text { Clay } \\ \text { 4. } & \text { Silty clay to clay }\end{array}$

5. Clayey silt to silty clay
6. Sandy silt to clayey silt
7. Silty sand to sandy silt
8. Sand to silty sand

9. Sand

10. Gravelly sand to sand

11. Very stiff fine grained*

12. Sand to clayey sand

* Overconsolidated or cemented.

Fig. 3 - Proposed soil classification chart from piezocone data by Robertson et al. 1986.

tance of the soil. It is necessary to correct the measured $q_{c}$ for unequal area effects using the following relationship, as indicated by Lunne et al. (1997):

$$
q_{t}=q_{c}+u(1-a)
$$

$q_{t}=$ corrected total tip resistance;

$u=$ pore-pressure generated immediately behind the cone tip;

$a=$ unequal area ratio, which depends on probe design characteristics.

The best interpretation methods combine both the tip and sleeve measurements with some type of pore pressure interpretation. It allows a very comprehensive logging with layer identification in the order of a few centimeters. Figure 3 shows an example of a chart for soil classification based on cone bearing and friction ratio (ratio of sleeve friction to cone bearing) as well as Pore-Pressure Parameter (ratio of excess pore pressure and net cone resistance) proposed by Robertson et al. (1986).

Considering the basic principles previously exposed the piezocone test interpretation show high capability for identifying thin layers of clays in sand strata and thin layers of sand in clay strata.

\section{CARAVELAS SITE}

\section{SITE DESCRIPTION}

Piezocone tests were performed to support the design of a pier for mineral transport, at the city of Caravelas, on the southern coast of the State of Bahia, Brazil. One of the piezocone tests was selected to compare with detailed paleogeological mapping produced with an integrated evaluation of geological mapping, vibrocore sampling, and radiocarbon studies (Andrade et al. 2003).

\section{Geological Mapping}

The Caravelas region was mapped in detail. Paleogeological distribution was defined and an evolutionary model was proposed explaining the factors that contributed to the strandplain formation. Andrade et al. (2003) concluded that the historic evolution and sediment distribution was controlled by sea level fluctuations during the Quaternary, with influence of seawater currents and coral barriers. The previously accepted theory of deltaic genesis for the strandplain was not confirmed by these authors.

Andrade et al. (2003) identified five major geologic-geomorphologic mapping units: Pleistocene beachridge terraces, lagoonal deposits, Holocene beach-ridge 


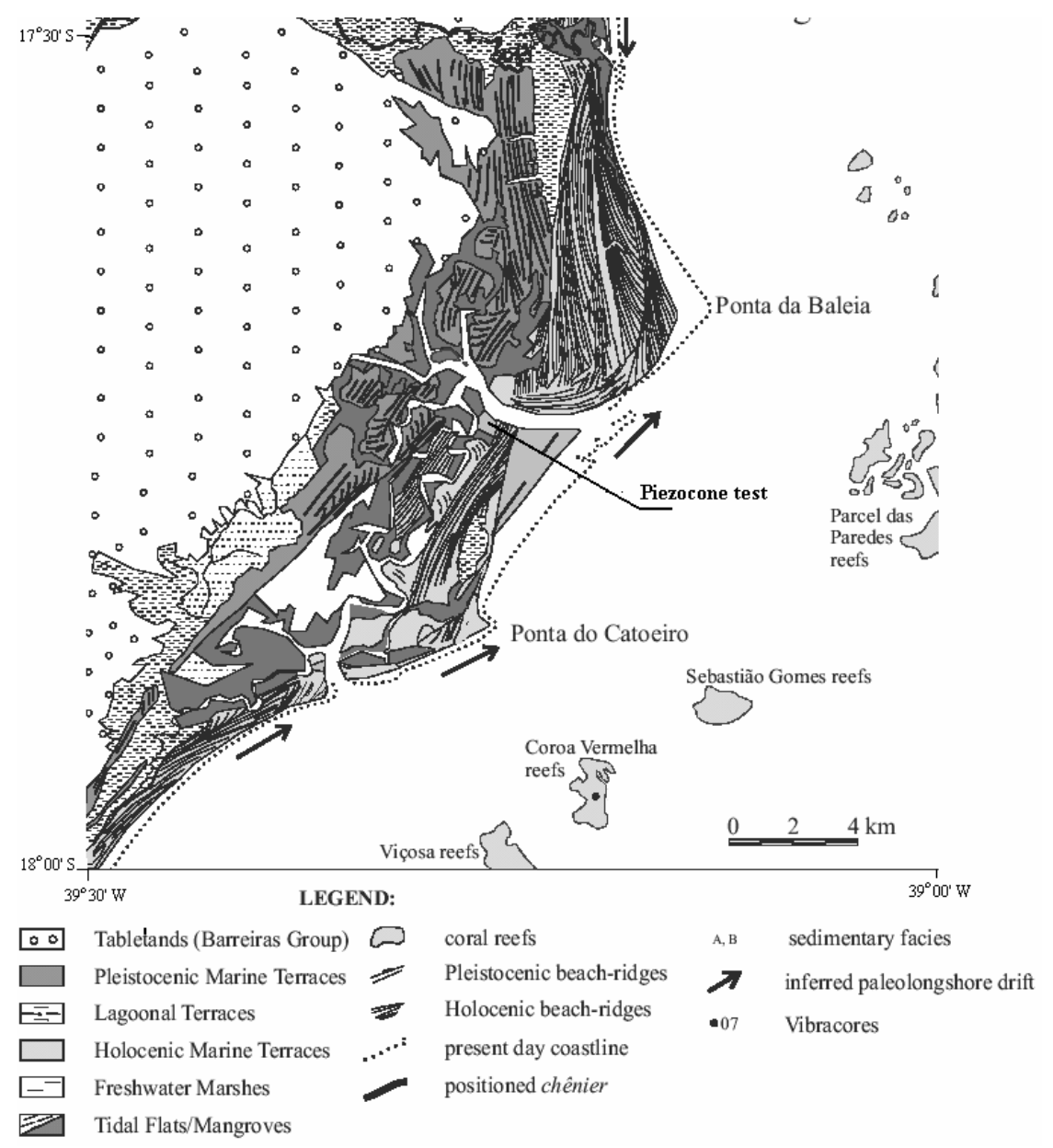

Fig. 4 - Geological setting of Caravelas region, indicating facies distribution and the piezocone test location (Modified from Andrade et al. 2003).

terraces, freshwater marshes, and tidal flats/mangroves. The last four units have been investigated in this study and they are indicated in Figure 4. Their main characteristics are described as follows.

The Lagoonal Terraces constitute gray to brown muddy sediments, with mollusk shells in life position. ${ }^{14} \mathrm{C}$ dating provided ages around 7,000-5,000 cal. years B.P. The Holocene Beach-Ridge Terraces are narrow and very well delineated, separated by low zones and commonly occupied by freshwater wetlands. They are made up of fine to medium yellowish sands, with planeparallel lamination dipping gently seaward, as the dominant sedimentary structure. Locally it rests directly on the top of a plastic gray mud of shoreface origin, and ${ }^{14} \mathrm{C}$ dating provide ages around 5,000-3,000 cal. years
B.P, with some variations. The Tidal Flats/ Mangroves are identified in the southern portion of the Caravelas plain. Mangrove swamps are comprised of vegetation like Rhizophora, Laguncularia, Avicennia and Terminalia on the upper intertidal areas. ${ }^{14} \mathrm{C}$ dating indicates ages of 300-800 cal. years B.P. The Freshwater Marshes occupy mainly the low-lying areas that separate the Pleistocene from the Holocene Beach-Ridge Terraces, the swales between beach-ridges, and riverine areas of tablelands. Sediments are mainly plastic muddy, rich in organic matter. A peat layer with variable thickness is sometimes present on top.

Nine facies associations were detected based on vibracore samples and outcrop information. They are grouped in two main zones: Littoral Zones Facies As- 
sociations (A1 to A4) and Lagoon/freshwater wetlands zone associations (B1 to B5) with the main characteristics presented in Table I.

\section{Piezocone Test REsults}

The piezocone test results for the Caravelas site are presented in Figure 5, where each graph represents the continuous register of each sensor, including corrected point resistance $\left(q_{t}\right)$, local lateral friction $\left(f_{s}\right)$, pore-pressure $(u)$, and friction ratio $\left(F_{r}\right)$. The test reached $35.0 \mathrm{~m}$ in depth, and the test interpretation indicates that there exist seven main layers, from A to F.

Piezocone test results are interpreted using a conventional soil classification chart proposed by Robertson et al. (1986) and the distribution of each layer is indicated in Figure 6. The test started at $2.0 \mathrm{~m}$ depth with the zero $(0)$ of the test equal to the zero $(0)$ of the presentday sea level. Layer A, from 2.0 to $4.3 \mathrm{~m}$, has high point resistance (12-15 $\mathrm{MPa}$ ), completely drained penetration, and very low friction ratios $(0.2-0.3 \%)$; it is homogeneous, and is classified as a very compact medium to coarse sand. Layer B, from 4.3 to $8.4 \mathrm{~m}$, has low point resistance (0.7-0.8 $\mathrm{MPa}$ ) with some high values (4 MPa), a heterogeneous pore-pressure response, which indicates lenses with drained penetration intercalated with lenses with undrained penetration, and friction ratios varying from 0.5 to $2.0 \%$, which indicate the presence of silt clay layers intercalated with centimetric fine sand lenses.

Layer C, from 8.4 to $11.4 \mathrm{~m}$, has high point resistance $(12-15 \mathrm{MPa})$ intercalated with lesser resistance levels (2-6 MPa), pore-pressure response indicating a completely drained penetration, and low friction ratios $(0.5-0.7 \%)$ with some higher values $(1-4 \%)$, which indicate the presence of sand materials, probably with fine intercalations of peat, where it is observed a high friction ratio and drained penetration. Layer $\mathrm{D}$, from 11.4 to $13.4 \mathrm{~m}$, has low point resistance, high porepressure values $(600 \mathrm{kPa})$, with three abrupt reductions at $11.9,12.1$, and $12.9 \mathrm{~m}$, which probably indicate the presence of organic matter, and a homogeneous friction ratio around $2 \%$, with a higher value equal to $7 \%$ on the top of the layer. This response is typically a siltclay (mud) material with a probable $0.1-0.2 \mathrm{~m}$ thick peat layer on the top.

Layer E, from 13.4 to $17.0 \mathrm{~m}$, has a high point resis- tance (6-8 MPa), negative pore-pressure indicating soil dilatancy, and a low friction ratio $(0.8-0.9 \%)$, which indicates a fine very compact sand. Layer F, from 17.0 to $32.4 \mathrm{~m}$, has low point resistance $(1.0-1.7 \mathrm{MPa})$, high pore-pressure values, with abrupt reductions at 19.0, $21.5,25.0$, and $27.0 \mathrm{~m}$, which probably indicate shell lenses. The sediment homogeneity and the great thickness are probably the result of a continuous sedimentation process. Layer $\mathrm{G}$, from 32.4 to $34.5 \mathrm{~m}$ has a variable response of all sensors, with point resistance from 2 to $10 \mathrm{MPa}$, pore-pressure from 0 to $1700 \mathrm{kPa}$, and friction ratios from 1 to $6 \%$, which indicate the intercalations of sand and silt-clay (mud) sediments.

The geological setting is defined as marine to transitional sediments formed by at least two TransgressiveRegressive cycles (Massad 1988) with thickness of about $60 \mathrm{~m}$. The piezocone test reached $34 \mathrm{~m}$ depth; the one presented in Figure 5 is similar to the other one carried out at the site and is representative of the stratigraphical model of the site.

\section{PARANAGUÁ BAY SITE}

\section{Site DesCRIPTION}

The site is located at the city of Paranaguá, on the coast of the State of Paraná, Brazil. High chloride concentration contaminated shallow water wells are used to supply water for local industries. The site-investigation program included fieldwork, dipole-dipole electrical profiling, resistivity piezocone tests, physical-chemical analysis of water, and interpretation of borehole logs. The integration of all test data allowed identification of the contaminated areas, and also guided the location of new water wells to be installed in the area.

\section{GEOLOGiCAL MAPPING}

The geological setting indicates a sedimentary sequence formed in a marine transitional environment, on the coastal plain of the State of Paraná. The site is on a strandplain with about $1500 \mathrm{~km}^{2}$ in plain topography limited by Paranaguá Bay and an Atlantic Ocean beach. The predominant map unit is the ancient beach ridges (Figure 7) formed by the successive positions of shoreline in a dynamic environment dominated by sea level fluctuation and lateral currents, in a partially protected environment, with possible interferences of various sub- 
TABLE I

Facies association detected on Caravelas region (Andrade et al. 2003).

\begin{tabular}{|c|c|}
\hline Facies A1 & $\begin{array}{l}\text { Rests on top of facies A2 and is characterized by fine to } \\
\text { medium yellowish quartz sands, locally with heavy minerals } \\
\text { and shells, and was interpreted as a result of deposition in } \\
\text { a beach-face environment. }\end{array}$ \\
\hline Facies A2 & $\begin{array}{l}\text { Constituted by gray to orange medium sands, with interbedded } \\
\text { fine to coarse sands and mud, and local layers of detrital } \\
\text { organic matter, situated immediately below facies A1. } \\
\text { It is interpreted as deposited on a shoreface environment, } \\
\text { mainly surf zones and shallower portions of shoreface. }\end{array}$ \\
\hline Facies A3 & $\begin{array}{l}\text { Made up of interbedded layers of light to dark gray muds } \\
\text { (thickness } 5 \text { to } 8 \mathrm{~cm} \text { ) and fine gray sands (thickness varying } \\
\text { from a few millimiters to over } 4 \mathrm{~cm} \text { ), below facies A } 2 \text {. } \\
\text { It is interpreted to be a result of deposition in a muddy } \\
\text { shoreface environment. }\end{array}$ \\
\hline Facies A4 & $\begin{array}{l}\text { Characterized by medium to coarse sands, and is interpreted } \\
\text { as having been deposited in an ebb-tidal delta environment. }\end{array}$ \\
\hline Facies B1 & $\begin{array}{l}\text { Characterized by gray-yellowish to dark gray muds. } \\
\text { A peat layer, with thickness varying from a few centimeters } \\
\text { to half meter, is frequently identified on the top of the facies. } \\
\text { It is interpreted as a result of deposition in a freshwater } \\
\text { wetland environment. }\end{array}$ \\
\hline Facies B2 & $\begin{array}{l}\text { Characterized by yellowish-brownish to dark gray muds, } \\
\text { without visible structures, and interpreted as having been } \\
\text { deposited in a supratidal environment. }\end{array}$ \\
\hline Facies B3 & $\begin{array}{l}\text { Characterized by plastic muds of yellowish-brown and gray color, } \\
\text { with intense bioturbation. It is interpreted as having } \\
\text { been deposited in an intertidal environment colonized by } \\
\text { mangroves plants. }\end{array}$ \\
\hline Facies B4 & $\begin{array}{l}\text { Subdivided in two sub-facies and interpreted as the result } \\
\text { of infilling of tidal creek. }\end{array}$ \\
\hline Sub-facies B4a & $\begin{array}{l}\text { Correspond to the lower subfacies of facies B4, constituted } \\
\text { mainly of sands with cross bedding and flaser bedding. }\end{array}$ \\
\hline Sub-facies B4b & $\begin{array}{l}\text { Correspond to the upper portion of facies B4, and is } \\
\text { predominantly muddy, with typical linsen bedding, } \\
\text { with increase bioturbation toward the top which causes a } \\
\text { mixture of sand and mud lenses. }\end{array}$ \\
\hline Facies B5 & $\begin{array}{l}\text { This facies is made up of massive gray clay, with varying } \\
\text { concentration of organic matter. It is interpreted as a result } \\
\text { of clay deposition in a subtidal environment with calm water, } \\
\text { probably inside a lagoon. }\end{array}$ \\
\hline
\end{tabular}




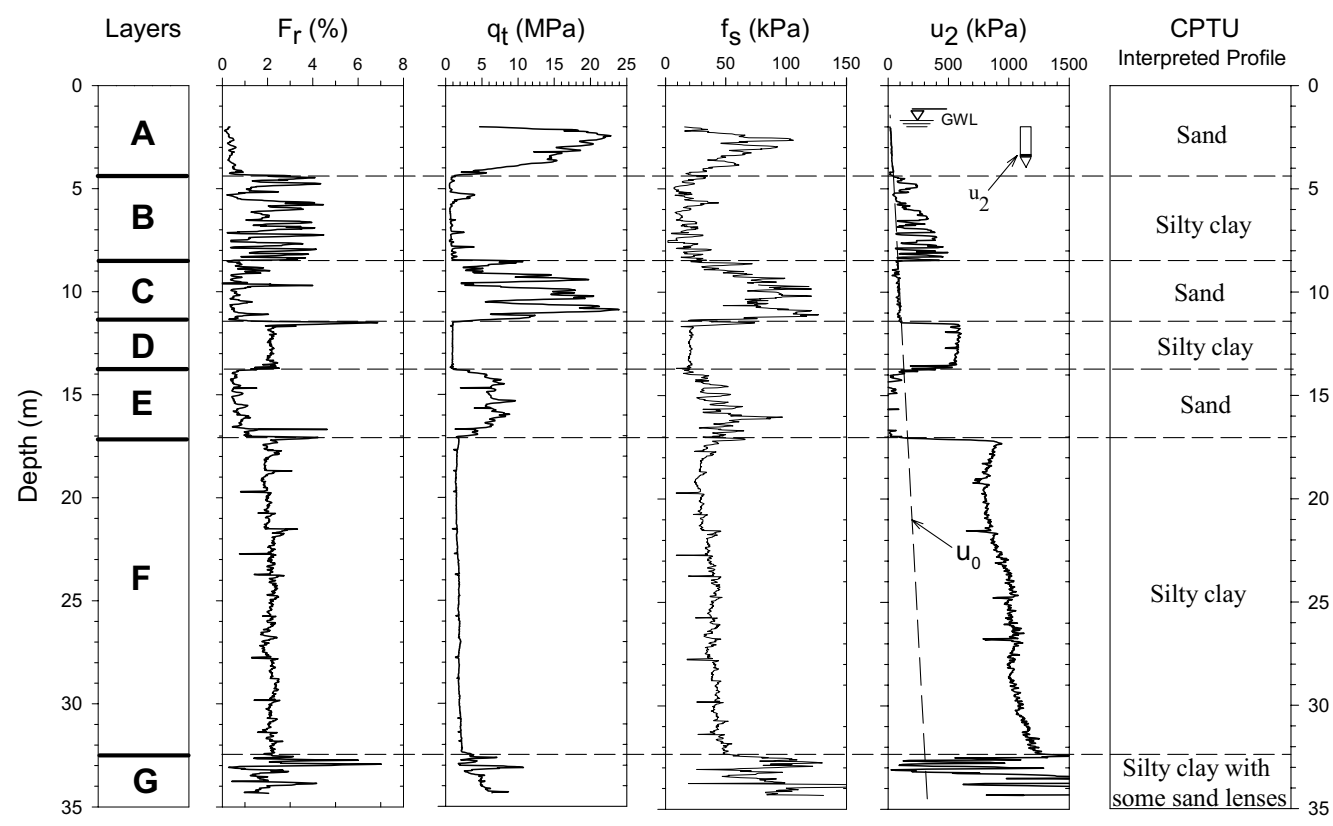

Fig. 5 - Piezocone test results for Caravelas region and the identification of seven main layers.

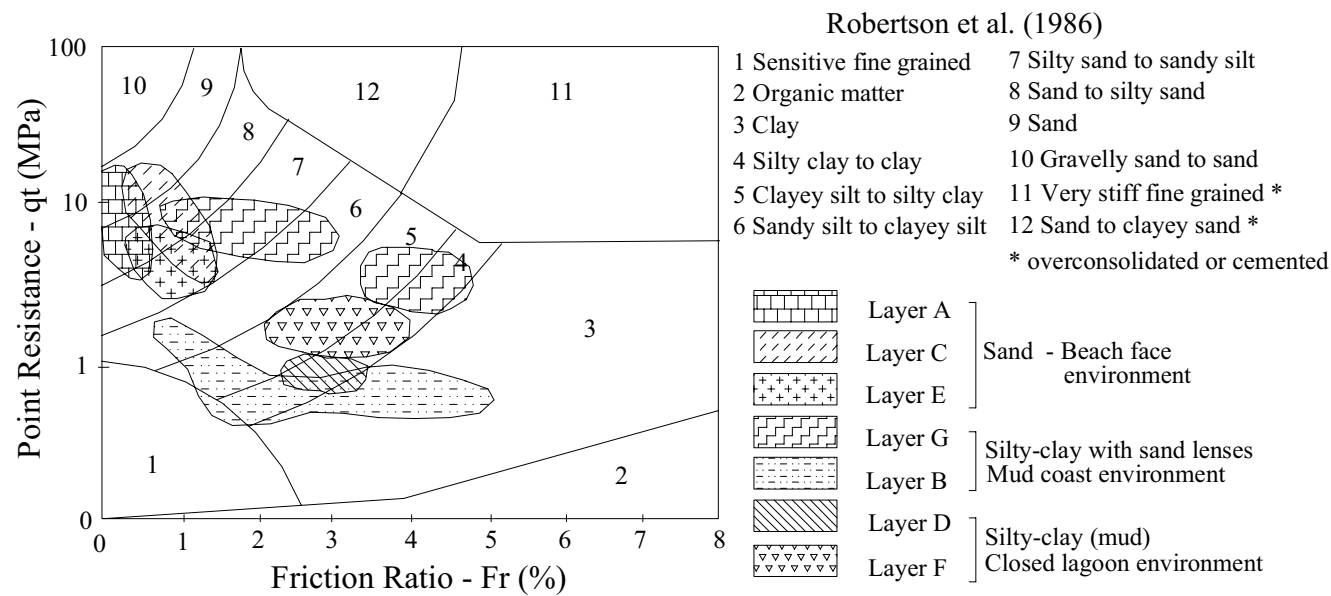

Fig. 6 - Robertson et al. (1986) classification chart and Caravelas site sediment distribution.

sequent morphological, edaphical, and geological factors (Angulo and Suguio 1994). This beach ridges unit has a complex evolution and frequently limit ancient paleolagoon and mangrove deposits. Angulo and Lessa (1997) suggested that only two transgressive and regressive periods may have occurred in the late Quaternary on this sector of the Brazilian coast, related respectively to the interglacial maximums of 120,000 and 5,100 BP. The Pleistocene sand barriers and the top of this layer are about $20 \mathrm{~m}$ in depth, which is related to the older interglacial maximum.

\section{Piezocone Test Results}

The result of one resistivity piezocone test is presented in Figure 8. This test provided two simultaneous kinds of information: the stratigraphycal profile at a very detailed level and a quasi-continuous resistivity profile. The level of the start of the piezocone test was $2 \mathrm{~m}$ above 


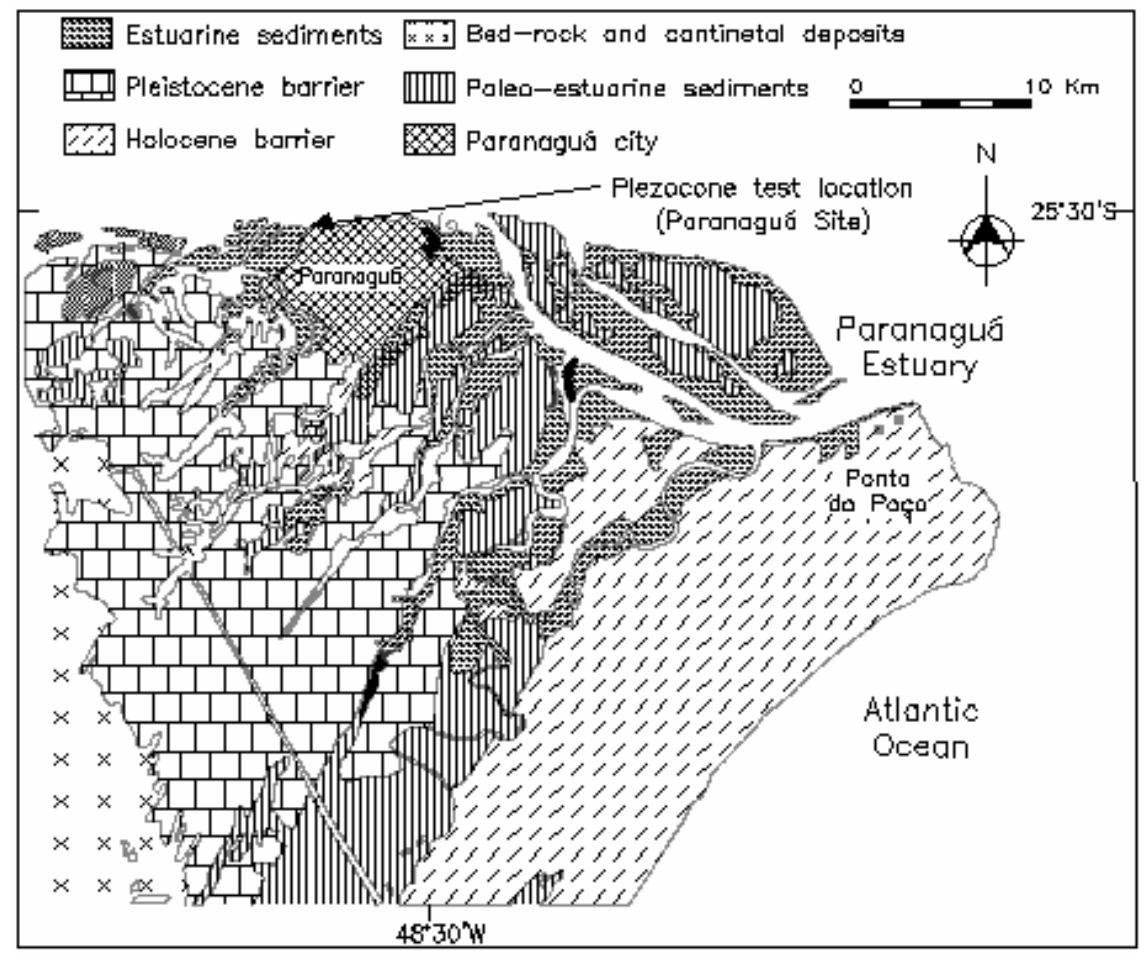

Fig. 7 - Geological setting of Paranagua region, indicating geologic units distribution and the site location. (Modified from Lessa and Angulo 1995).

the present-day sea level.

Piezocone test results are interpreted using a conventional soil classification chart proposed by Robertson et al. (1986) and the distribution of each layer is indicated in Figure 9. The stratigraphycal profile shows three main units: A - sandy sediment, from 0 to $13.0 \mathrm{~m}$; B - muddy silt clay sediment, from 13.0 to $23.0 \mathrm{~m}$; and $\mathrm{C}$ - sandy sediment, from 23.0 to $34.0 \mathrm{~m}$. The layer $\mathrm{C}$ is made up of sand with point resistance varying between 5 and $25 \mathrm{MPa}$, low friction ratio ( 0.5 to $1 \%)$ and a completely drained penetration (excess pore-pressure $=0$ ). Between 23.0 and $25.0 \mathrm{~m}$ there exists a silt clay thin layer that probably represents lagoonal environments formed by seawater ingression pulses (storms) during a transgressive cycle. At 26.0 and $30.0 \mathrm{~m}$ depth there are indications of sea level fluctuations, in a similar environment but with distinct energy intensity. The friction ratio is practically constant; variations in the point resistance and local friction were registered, with differences between the layers at $30.0-34.0 \mathrm{~m}$ and at $26.0-30.0 \mathrm{~m}$ depth. Probably the differences are related to grain size distri- bution or to shell concentrations, which can change compressibility, which is sensible to the piezocone. The transition to the upper layer (B) is marked by fining upward, and is transitional, because there is a zone, between 23.0 and $26.0 \mathrm{~m}$, where the properties of each main layer are mixed in alternate sublayers, indicating rapid variations in the depositional environments. This characteristic is indicated in the classification chart (Figure 8) where the layer $\mathrm{C} 1$ shows a mixture of soils from sand to silt clay. The piezocone test result, with a more detailed interpretation, allows the subdivision of this interval into sublayers of sand and silt-clay sediments with thickness varying from 0.2 to $0.6 \mathrm{~m}$.

The intermediate layer (B) is made up of silt clay mud, with point resistance varying from 1 to $3 \mathrm{MPa}$, friction ratio varying from 1 to $2.5 \%$ and high excess pore-water pressure during piezocone penetration. Porepressure and friction ratio growing-up downward can indicate higher clay content on the layer's base, with some contribution of the effective vertical stress component. The high homogeneity and the grain size distribu- 


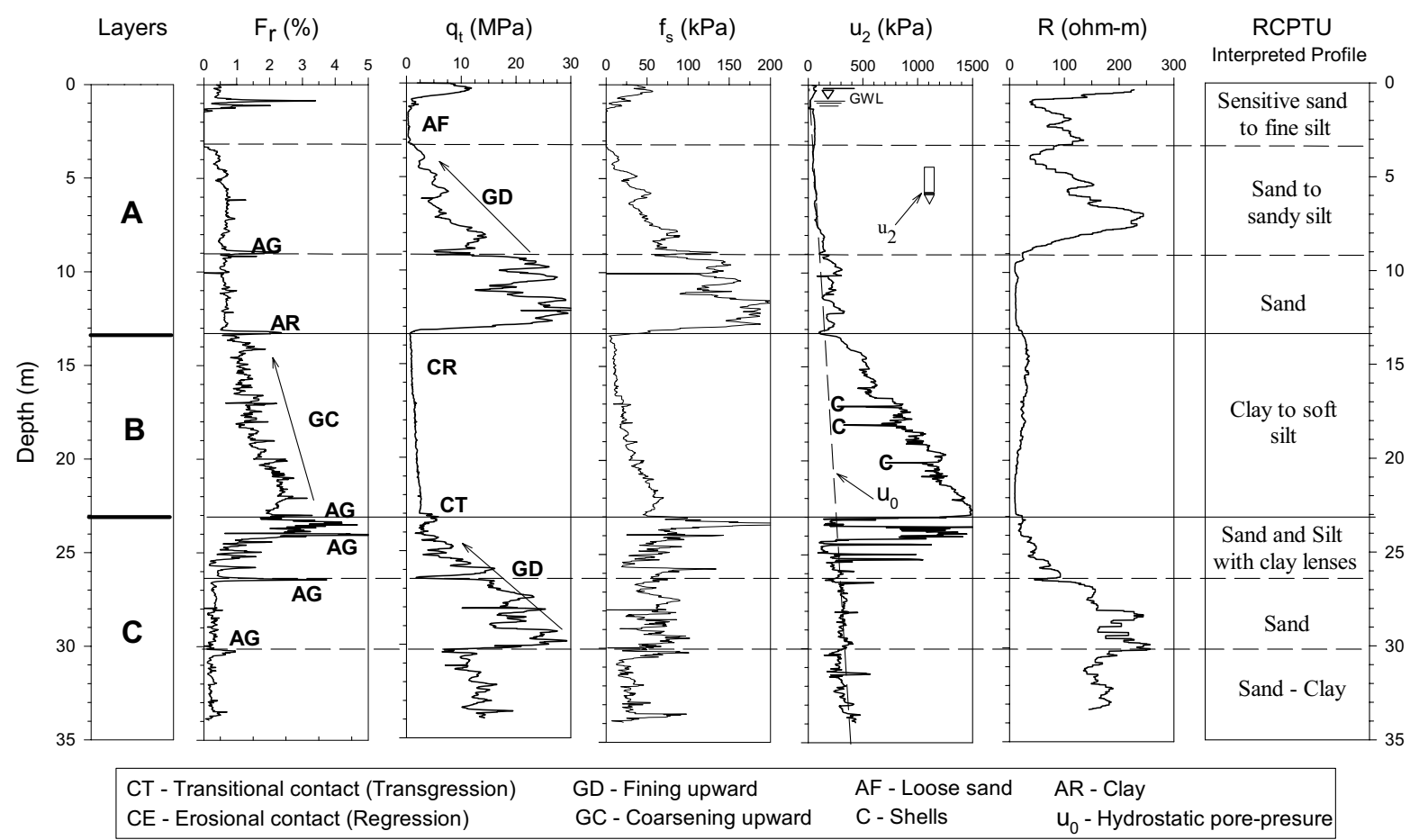

Fig. 8 - Interpretation of resistivity piezocone test results for stratigraphic logging and the depositional environmental conditions in Paranaguá site sediments. (De Mio et al. 2005).
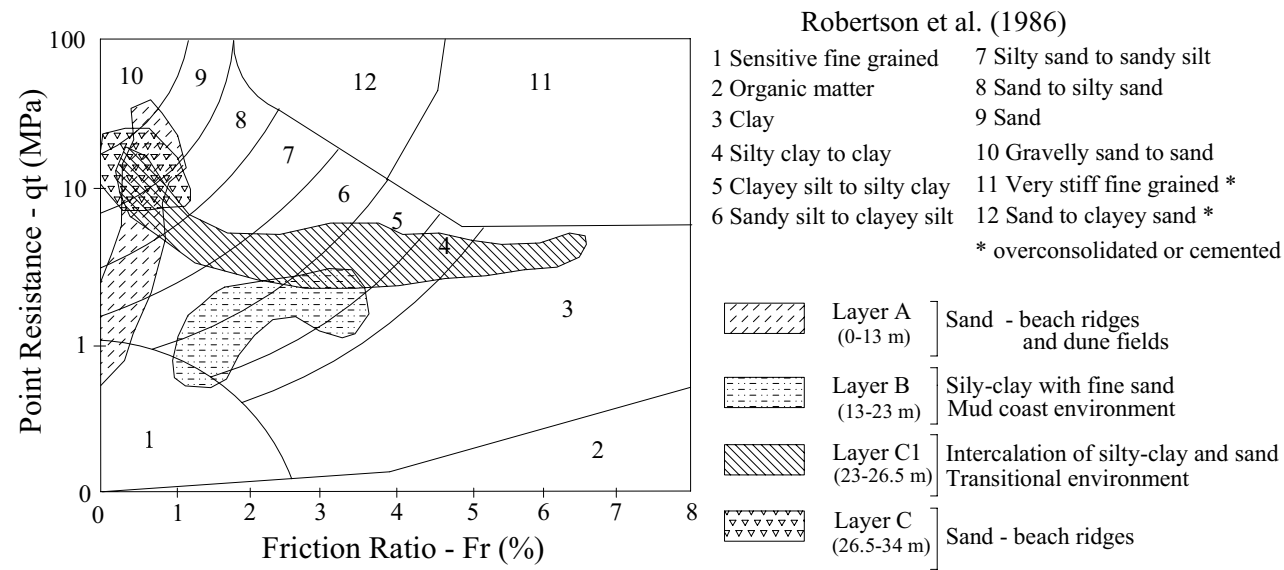

Fig. 9 - Robertson et al. (1986) classification chart and Paranaguá site sediment distribution.

tion indicate a calm depositional environment, probably on a protected and closed bay, without storm influences. At 17.0, 18.0 and $20.0 \mathrm{~m}$ depth, quick pore-pressure reductions, with short or no register on point resistance or friction ratio, are similar to the ones described by Amorosi and Marchi (1999), and have been interpreted as thin shell layers. The transition to the upper layer (A) is effectively marked by $q_{t}, f_{s}$ and $u$ records and it is abrupt, representing an erosive contact on a regressive phase seawater fluctuation. Friction ratios from 3 to $6 \%$ can represent clay layers deposited on transitional lagoonal environments. 
The layer A, from 0 to $13.0 \mathrm{~m}$, is predominantly sand, fining upward. Between 1.0 and $3.0 \mathrm{~m}$, there is low point resistance sediment with a very low friction ratio, probably loose sand from dune fields. The interval between 9.0 and $13.0 \mathrm{~m}$ depth is made up of sand sediments with point resistance around $20 \mathrm{MPa}$, friction ratio about $0.5 \%$ and low pore-pressure varying from 0 to $250 \mathrm{kPa}$. The variation in point resistance and the irregular pore-pressure response probably indicate the presence of sand beaches with some occasional silty clay lenses, similar to the superficial map unit defined by beach ridges and the lagoons on a present beach sediment or eolian sand depositional environment. The layer between 3.0 and $9.0 \mathrm{~m}$ depth has point resistance values varying from 5 to $12 \mathrm{MPa}$, cone penetration completely drained, and a friction ratio of about $0.5 \%$. The drained penetration is related to low fine content, which indicates the presence of clean sand, different from the layer above. Probably it represents an eolian environment deposition with some influence of pedogenetic processes.

\section{GUARUJÁ BAY SITE}

\section{SITE DESCRIPTION}

The site is located at the city of Guarujá on the central coast of the state of São Paulo, Brazil. An investigation program for harbor infrastructure development was conducted at the site. One piezocone test result and one borehole were selected for stratigraphical analysis, considering the geological setting and the previous researches developed by Martin et al. (1993) and Massad et al. (1996).

\section{GeOlogical MAPPING}

Following the conception of Martin et al. (1993), the Pleistocene sediments were formed during the Cananéia Transgression (123,000 years). They are denominated informally as Transitional Clays or Transgressive Sands (ATs), normally deeper than 20-25 m with high homogeneity and uniformity when compared to other sediments. The upper sediments are related to the Santos Transgression (7,000 years), and they are informally denominated as Bay and Fluvial-Lagoonal Sediments (SFL). They are made up of clay and sand, with high shell concentrations, on lagoonal, bays and estuarine environments. The geological setting of Guarujá region is indicated in Figure 10. The stratigraphical profile is presented in Figure 11 and it is divided into six main units based on interpretation of piezocone test results.

\section{PiEZOCONE TEST RESUlts}

Piezocone test results are presented and interpreted. The CPTU test reached $41 \mathrm{~m}$ depth and the level of the start of the test was $1 \mathrm{~m}$ above present-day sea level. Piezocone test results are interpreted using a conventional soil classification chart proposed by Robertson et al. (1986) and the distribution of each layer is indicated in Figure 12. The test interpretation indicates that there exist six main layers, from $\mathrm{A}$ to $\mathrm{F}$, and subdivisions within layer B: B1, B2 and B3.

Layer F, from 31.0 to $40.0 \mathrm{~m}$, is made up of silt clay sediments, point resistance varying from 2 to $3 \mathrm{MPa}$, constant friction ratio about $2 \%$ and a homogeneous porepressure response around $1200 \mathrm{kPa}$. Quick reductions on the pore-pressure values at 32.5, 33.0, 35.0 and $38.0 \mathrm{~m}$ indicate thin layers of sand or mollusk shells; probably at the $35.0 \mathrm{~m}$ depth this response is due to a sand layer, while the others are due to shell layers. The transition to the upper layer (E) is abruptly marked by $q_{t}, F_{r}$ and $u$ records, indicating an erosional contact.

Layer E, from 28.0 to $31.0 \mathrm{~m}$ depth, represents a sand layer, with point resistance varying from 6 to $9 \mathrm{MPa}$, friction ratio around $0.5 \%$ and a drained penetration, a typical sand behavior. At about $30.0 \mathrm{~m}$ depth a reduction on the point resistance and an increase on friction ratio and pore-pressure values indicates a thin clayey silt layer, which is evidence of environmental deposition changes, probably on a beach face or near shore environment, with mud sediment. It can represent a fluctuation in sea level that resulted in an intermediate environment in the transition to the silty clay sediments of layer D, subsequently described.

The sediments of layer D, from 26.0 to $28.0 \mathrm{~m}$ depth, are made up of silty clay mud, with point resistance around $2 \mathrm{MPa}$, friction ratio of $2 \%$ with some higher picks, and pore-pressure around $500-900 \mathrm{kPa}$. At the layer base there is a thin seam with about $0.3 \mathrm{~m}$, classified as clay, and probably with a fining upward inside the layer. The transition to layer $\mathrm{C}$ is marked by the point resistance and pore-pressure registers, and appears to be gradational, but it is not well defined, probably indicat- 


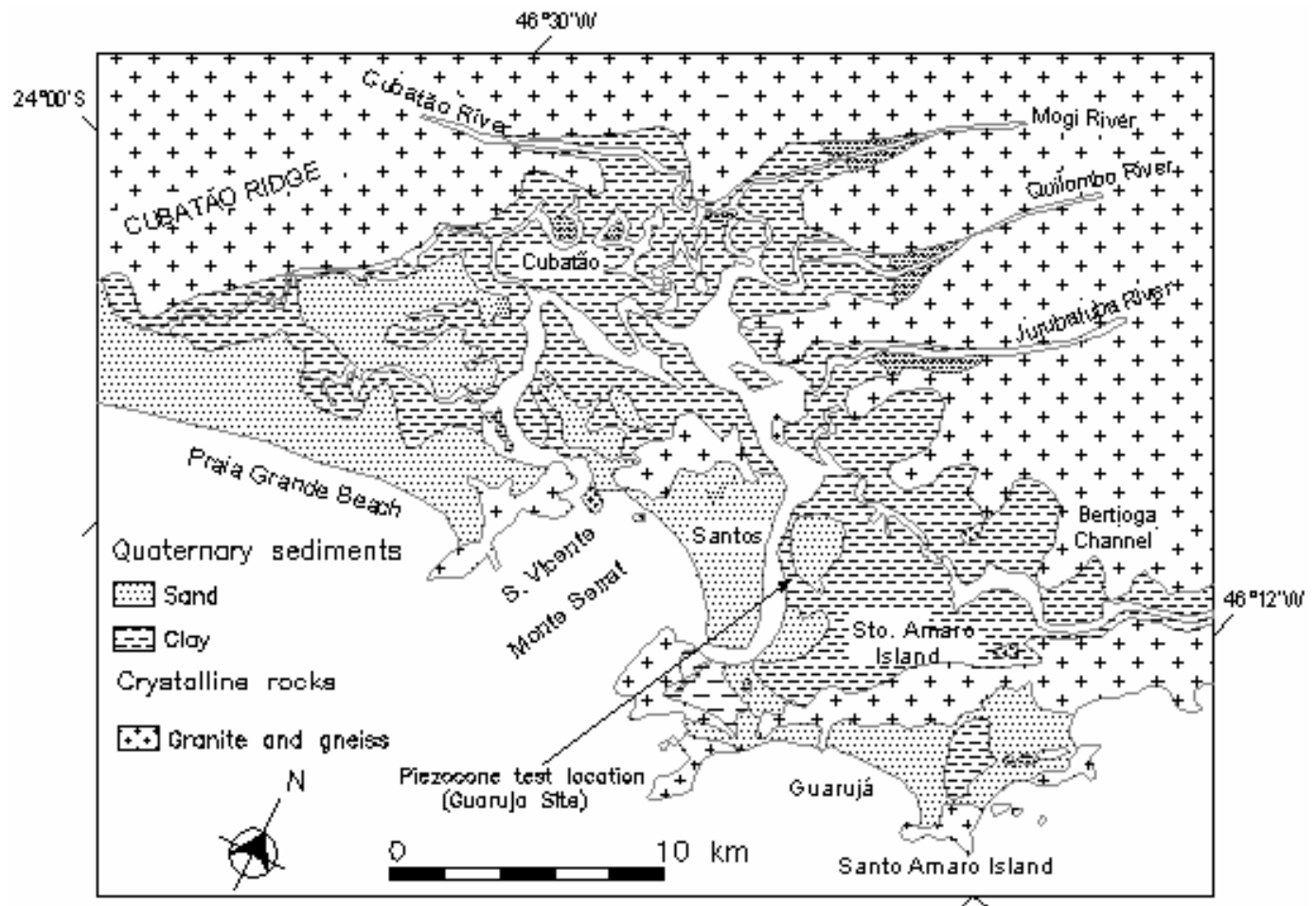

Fig. $10-$ Geological setting of Guaruja region, indicating geologic units distribution and the site location. (Modified from Massad 1988).

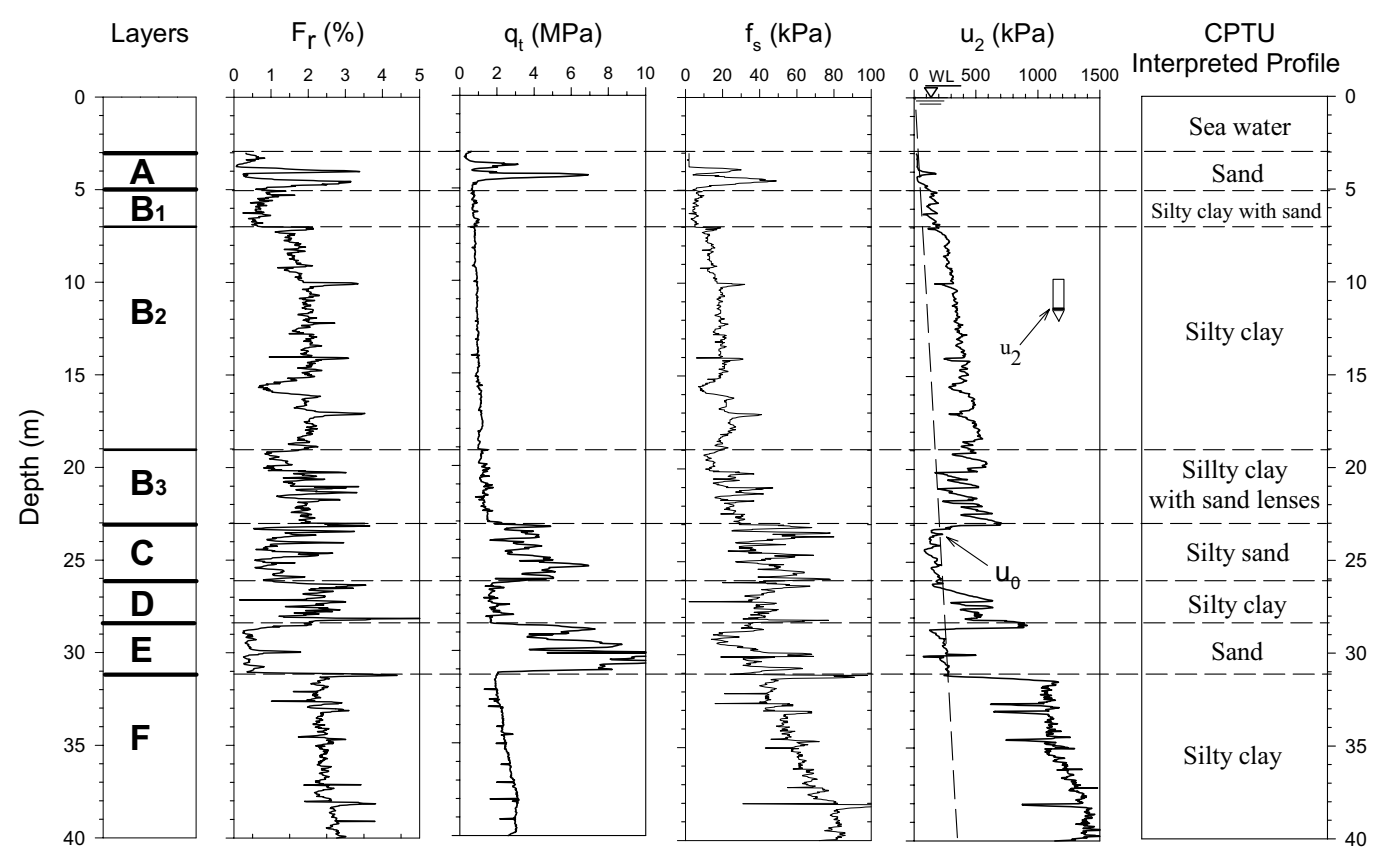

Fig. 11 - Interpretation of a piezocone test result carried out at Guarujá bay site. 


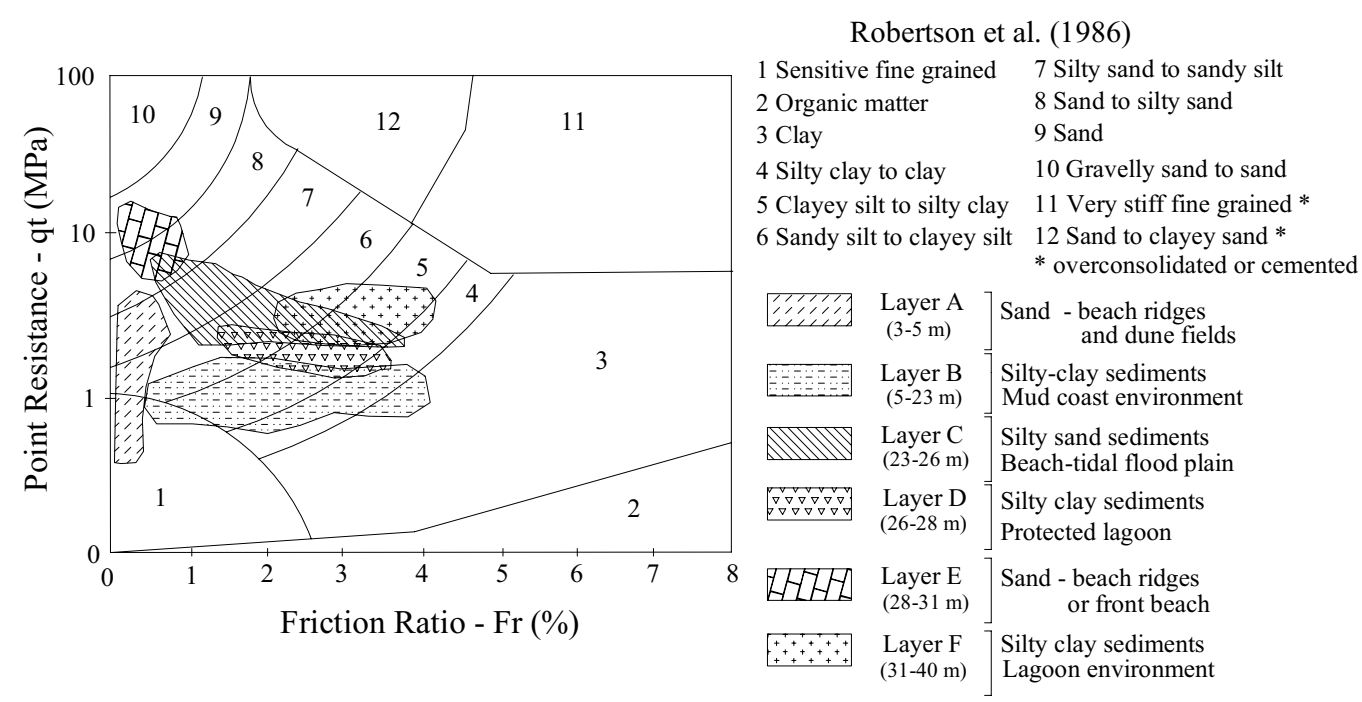

Fig. 12 - Robertson et al. (1986) classification chart and Guarujá's bay sediment distribution.

ing that the environmental conditions had changed at low rates and had involved energy variations modifying the grain size distribution of the sediments. This particularity can be related to the protected bay environment, and the different responses of the sediment rate delivery related to sea level fluctuations.

Layer C, from 26.0 to $23.0 \mathrm{~m}$ depth, is made up of silty sand sediments, as indicated by point resistance varying between 3 and $6 \mathrm{MPa}$, friction ratio varying between 1 and $3 \%$ and no excess pore-pressure. The registered variations on $q_{t}$ and $R_{f}$, without variations on $u$, probably indicate a grain size or soil density variation, possibly associated with mollusk shell concentration. The transition to layer B is marked by point resistance and pore-pressure response, and probably is a transitional contact from sandy sediments to silty clay with sand sediments, on a transgressive phase.

Layer B, from 5.0 to $23.0 \mathrm{~m}$ depth, is silty clay sediment locally interbedded with silty sand sediment, which resulted in the layer subdivision. The lower one, sublayer B3, from 19.0 to $23.0 \mathrm{~m}$ depth, represent a transition layer, where silty clay sediments are intercalated with sandy sediments, as indicated by the quick reduction in the pore-pressure response associated with some higher point resistance values. Sublayer B2 has a higher homogeneity with pore pressure around 300 to $400 \mathrm{kPa}$ and a friction ratio around $2 \%$, which indicate that it is silty clay sediment. At 10.0 and $15.0 \mathrm{~m}$ depth the porepressure and friction ratio response indicate a reduction in the values, and as the point resistance sensor does not indicate high values, it is possibly related to the presence of mollusk shell lenses. Sublayer B1, from 5 to $7 \mathrm{~m}$ depth has a low friction ratio around $1 \%$ and a low porepressure value around $200 \mathrm{kPa}$, which probably represent loose silty sand sediment, deposited in an environment changing to the conditions identified at layer $\mathrm{A}$.

Layer A, from 5.0 to $3.0 \mathrm{~m}$ depth, is made up of sand intercalated with silty clay sediments, tip resistance varies between 1 to $6 \mathrm{MPa}$, friction ratio from 0.5 to $3 \%$ and pore-pressure penetration is predominantly drained. The upper portion of the profile, from 0 to $3.0 \mathrm{~m}$, is seawater with very soft clay suspension on the base, recently removed by dredging jobs.

\section{DISCUSSIONS}

The piezocone test has recently been introduced for the identification and interpretation of sedimentary sequences, with very stimulating results (Amorosi and Marchi 1999). The lack of samples is compensated by the high profiling capability and the reduced time to acquire each profile. The extensive geotechnical experience, mainly on sedimentary soils, has supported layer identification and soil classification (Robertson et al. 1986, Douglas and Olsen 1981, Hegazy et al. 1991, 
Fellenius and Eslami 2000).

Piezocone test results for all the three sites will now be discussed to identify the general characteristics of each site and the correspondences with the superficial mapping units and the depositional environment.

\section{Caravelas Site}

Interpretation of piezocone test results from Caravelas site is compared to the geological mapping presented by Andrade et al. (2003). A good correlation was observed between them, supported by the basic sedimentary geological principle where the superficial mapping units are equally identified on the vertical profile from the same sequence. In a similar way, the sediment profile is related to the sea level fluctuations that have controlled the evolution of this sedimentary sequence. There were identified, as a tentative interpretation, the three transgressionregression cycles presented in Figure 13.

The deepest layer G (Figure 5) represents the base of the investigated profile and is made up of heterogeneous sediments, with silty clay with some sand lenses. It indicates quick changes in the environment, probably because of quick sea level variation at the end of the last interglacial regression, supposed to have occurred about 20,000 years BP, but it is not conclusive. The sediments are similar to Facies A3 defined by Andrade et al. (2003) and probably are related to a mud coast environment. Layer F, typically silty clay (or mud), in a calm and low energy environment, probably within closed lagoons, similar to the one described by Andrade et al. (2003) as Facies B5. The transition to layer E, which is made up of a compact sand, marks an erosional contact very well defined by the pore-pressure and friction ratio records. The environment was probably a beach, similar to Facies A1 described by Andrade et al. (2003), and indicates that the mud sediments from unit $\mathrm{F}$ were eroded in a regressive phase, probably related to the sea level drop of about 4,000 years BP. In the sequence, a new transgressive phase resulted in the deposition of layer D, made up of silty clay sediments, deposited within calm protected lagoons, probably related to the end of the 3,500 years BP transgression. Layer $\mathrm{C}$ is made up of sand with lenses of soft materials, probably peat or organic matter, with some similarities to Facies A2 sediments, described by Andrade et al. (2003), which are characteristic of beach coast environments with organic matter detritus. Layer B is constituted of decimetric levels of silty clay (mud), with centimetric lenses of fine to medium sand, very similar to the ones described as Facies A3, by Andrade et al. (2003) on a mud coast environment. Layer A is made up of sand, with similarities to Facies A1 described by Andrade et al. (2003). Thus, there are some good similarities between the mapping units and the piezocone test interpretation, but it is necessary to combine them with other techniques, like sampling, ${ }^{14} \mathrm{C}$ dating and others, for a better interpretation of the environmental changes during the Quaternary.

\section{PARANAgUá Site}

The geological mapping units of Paranaguá site were mapped by Lessa and Angulo (1995), and indicate that the tops of the sand units are at about $8 \mathrm{~m}$ depth for the Holocene beach ridges and $20 \mathrm{~m}$ depth for the Pleistocene beach ridges. They suggest that significant sea level fall after the transgressive period produces sand deposits as mixtures of transgressive and regressive sediments. Organic and mud-rich sediments under the sand layer are interpreted as Holocene estuarine deposits. They indicate that barrier sand deposits migrated over the estuarine environment as sea level rose. Piezocone test results (Figure 8) indicate two layers of sand barriers, the upper layer, between 9.0 and $13.0 \mathrm{~m}$, and the other between 23.0 and $34.0 \mathrm{~m}$ (the end of the piezocone test). Piezocone test results indicated detailed transition characteristics, and allowed differentiation of erosional and transitional contacts, identifying the silty clay mud layer between the two sand barriers deposited between 13.0 and $23.0 \mathrm{~m}$ depth. The transition of the lower sand barrier deposit to the estuarine deposit is characterized by an intercalation of clay to soft silt layers between 23.0 and $29.0 \mathrm{~m}$ depth. It probably indicates that lagoonal deposits were formed by pulses of marine ingression in a transgressive cycle. Thus, the contact between the lower sand barrier and the estuarine deposit is transitional and represents the gradual development of new environments due to sea level fluctuations. As the lower sand barrier is considered of Pleistocene age, the two upper layers indicate one transgressive and regressive period from the Holocene age. Considering this inter- 


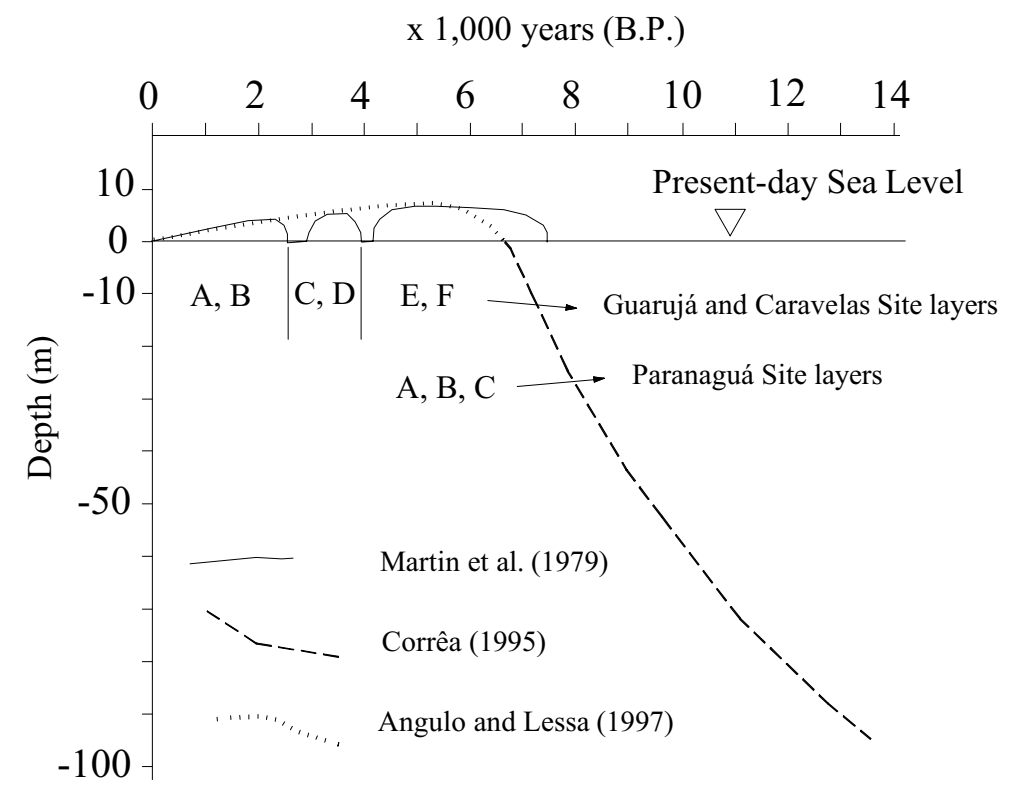

Fig. 13 - Sea level fluctuations, indicated by several authors, and the indication of the main layers defined from piezocone test interpretation, for Caravelas, Guarujá and Paranaguá sites.

pretation, the sediment sequence does not indicate other high-frequency oscillations of the sea level, as stated by Martin et al. (2003) and other authors, for most of the Brazilian coast.

\section{GuARUjá Site}

Interpretation of piezocone test results for Guarujá Bay also show a good correlation between the superficial mapping units and the profile interpreted from CPTu. It can be seen in Figure 11 that the deepest silty clay layer, with the top at $31.0 \mathrm{~m}$ depth, probably represents Transitional Clays (AT), and is very homogeneous, as indicated by piezocone test interpretation, and was formed during the Pleistocene Cananéia Transgression (123,000 year BP), following the conception presented by Martin et al. (1993). The upper sediments were probably formed during the Holocene Santos Transgression (7,000 year BP), and layer intercalation indicates high frequency oscillations in sea level. The deepest sand layer, from 28.0 to $31.0 \mathrm{~m}$ depth, seems to have an erosional contact on the base and a transitional contact on the top. In a different manner, the silty sand layer between 23.0 and $26.0 \mathrm{~m}$ depth seems to have transitional contact on the top and on the base. This supports the assumption of Lessa and Angulo (1995) that the sandy layers can represent regressive or transgressive deposits, and are frequently present as a complex association.

\section{General Discussion}

Interpretation of piezocone test results shows distinct association of sediments, each one composed of a silty clay mud layer and a sand layer, very similar in the Caravelas and Guarujá sites. Each association is represented by layers $\mathrm{F}$ and $\mathrm{E}$; D and $\mathrm{C}$; B and A, probably related to transgressive (mud sediments) and regressive (sand sediments) cycles. Figure 13 indicates a tentative relation between the described associations and the assumed sea level changes. On the sedimentary sequence from the Caravelas site, where Andrade et al. (2003) have identified a direct relation with sea level changes, it is possible to verify that the two sea level reductions in the years 4,000 and 2,500 BP, as presented by Martin et al. (2003), seem to be related to the layers identified in the piezocone stratigraphical profile. The upper profile layers have a high degree of variability, representing more frequent oscillations in sea level or inversions, as can 
be expected from the variations in sea level in the past 5,000 years BP, and their direct influence on sediment deposition and environmental distribution.

The piezocone test, at the Paranaguá site, reached $34.0 \mathrm{~m}$ depth, in a compact sand sediment. The lower sand layer is considered to be from the Pleistocene age, and the association composed by the upper sand layer and the mud layer represents only one sediment association probably related to a transgressive and regressive event. The sea level curve proposed by Angulo and Lessa (1997) is compared to the layers defined from piezocone test interpretation in Figure 13.

The thickness of each layer represents the time span in which the environmental conditions have persisted relatively constant, resulting in specific sediment profile characteristics, which can be analyzed to understand the environmental changes. This depositional time span has the scale related to the sediment delivery rate and can reflect erosional rates of the source area. The differences between layer thicknesses at the investigated sites probably represent different sediment delivery rates or different relative sea level fluctuation rates.

${ }^{14} \mathrm{C}$ dating associated with additional piezocone tests can probably confirm this hypothesis. Beyond this, the sea level fluctuations produce consolidation of mud sediments that can reduce the thickness of each layer and interfere with the interpretation of the original thicknesses of sediment layers at the time of deposition. Geotechnical parameters can help to answer this and support the sediment deposition history, as stated by Massad et al. (1996).

There is a remarkable correspondence between the maximum and minimum sea levels according to different authors; however, Angulo and Lessa (1997) have questioned the oscillations in sea level on the Paraná coast, as well as the ones indicated by Martin et al. (2003) for most of the Brazilian eastern shore. This statement was questioned by Martin et al. (1998), who indicated that there are several pieces of evidence which strongly confirm the existence of the high-frequency oscillations in sea level during the late Quaternary. Thus, the interpretation of piezocone testing clearly indicates that the sediment sequences have different patterns when comparing results from the Caravelas and Guarujá sites with results from the Paranaguá site. This assumption supports the proposition of Angulo and Lessa (1997) that the high frequency oscillations of sea level were not identified in the Paranaguá region. This confirms the conclusions of Bezerra et al. (2003) that variations in sea level fluctuations can be significantly influenced by local causes, mainly because different tectonic histories.

The deeper portions of the piezocone results are probably related to the Pleistocene age, but it is difficult to relate the thickness of each layer to specific dates. Dating of specific layers of sediments in conjunction with piezocone test results probably could contribute to a better interpretation of Brazilian sea level curves.

\section{CONCLUSIONS}

It was observed that the geological-mapping units and the interpretation of piezocone test results agree well for the three study sites. The high profiling resolution of the piezocone test allows the identification of sedimentological characteristics as thin layers of sand, clay, shells or peat; identifies the layers' transition characteristics, as erosional (abrupt) or transitional (gradual); and confirms that piezocone testing is very useful for stratigraphical logging.

Based on the investigated test data, it seems that piezocone test results can distinguish Pleistocene from Holocene deposits, but further research is necessary to clarify this. The transition between sand and clay layers is erosional or transitional, and indicates environmental changes, controlled by the coast morphology, sea level fluctuations and ocean currents. The obtained detailed profiles, based on piezocone test interpretation, can help to identify different environments and guide sampling. This approach is a less expensive site investigation, which can be combined with other current testing methods. Piezocone testing does not provide samples; however it produces a continuous profile very rapidly, without the restrictions and high costs of sampling underwater loose sediments. The sand and mud layer sequences of intercalation are similar at the Guarujá and Caravelas sites, but the thickness and depth of layers are variable. This can indicate that the causative agents were the same in both regions, but sediment supply rates changed, probably because of shore morphology, resulting in a similar sequence of facies associations produced by sea level fluctuations. The sediment 
sequence from the Paranaguá site indicates that the evolution of this sector of the Brazilian coast is different from other sectors of the Brazilian coast. This confirms the conclusions of Bezerra et al. (2003) that variations in sea level fluctuations can be significantly influenced by local causes, mainly because different tectonic histories.

\section{ACKNOWLEDGMENTS}

The authors would like to thank Prof. Kenitiro Suguio, from Instituto de Geociências, Universidade de São Paulo (IG-USP), for the stimulus, suggestions and especially for reviewing this paper. The support from the Fundação de Amparo à Pesquisa do Estado de São Paulo (FAPESP) for funding this research was much appreciated. We also would like to thank an anonymous referee for his comments and suggestions.

\section{RESUMO}

Correlações entre unidades de mapeamento em bacias sedimentares costeiras e a interpretação dos resultados de ensaios de piezocone são apresentadas e discutidas, a partir de exemplos da planície de Caravelas (Estado da Bahia) e das baias do Guarujá (Estado de São Paulo) e Paranaguá (Estado do Paraná), Brasil. O reconhecimento de que o ambiente de sedimentação foi controlado principalmente pelas flutuações do nível do mar levou a interpretação de seqüências de sedimentos transgressivos e regressivos, que têm um bom ajuste com as curvas de variação do nível do mar aceitas para estas regiões. A interpretação dos resultados dos ensaios de piezocone mostra que as seqüências sedimentares dos sítios Caravelas e Guarujá são semelhantes e têm uma boa correlação com a curva de variação do nível do mar aceita para a região de Salvador, Estado da Bahia. Os resultados do ensaio de piezocone no sítio Paranaguá, entretanto, indicam uma seqüência de sedimentos diferente das anteriores, mostrando boa relação com a curva de variação do nível do mar aceita para a região de Paranaguá. Os resultados mostram a grande aplicabilidade dos ensaios de piezocone para perfilagem estratigráfica e sugerem que é possível integrálos a outras técnicas convencionalmente utilizadas nos estudos paleo-ambientais do Brasil, o que está de acordo com abordagens recentes utilizadas em pesquisas internacionais nessa área do conhecimento.

Palavras-chave: perfilagem estratigráfica, ensaio de piezocone, paleo-ambientes, mapeamento geológico.

\section{REFERENCES}

ABNT MB-3406. 1994. Solo - Ensaio de penetração de cone in situ CPT, método de ensaio, CB-O2, 10 p.

AMOROSI A AND MARCHI N. 1999. High-resolution sequence stratigraphy from piezocone tests: An example from the Late Quaternary deposits of the southeastern Po Plain. Sed Geol 128: 67-81.

Andrade ACS, Dominguez JML, Martin L AND BITTENCOURT ACSP. 2003. Quaternary evolution of the Caravelas strandplain - Southern Bahia State - Brazil. An Acad Bras Cienc 75: 357-382.

Angulo RJ AND LessA GC. 1997. The brasilian sea-level curves: A critical review with emphasis on the curves from the Paranaguá and Cananéia regions. Mar Geol 140: $141-166$.

Angulo RJ And Suguio K. 1994. Problems in the interpretation of Quaternary Beach Ridges: the example from Coastal Plain of Paraná (Brazil). An Acad Bras Cienc 66: $347-358$.

ASTM D-3441. 1986. Standard test method for deep quasistatic, cone and friction-cone penetration tests of soils, p. $414-419$.

Bezerra FHR, BARreto AMF AND Suguio K. 2003. Holocene sea-level history on the Rio Grande do Norte State coast, Brazil. Mar Geol 196: 73-89.

Colas S, Casamor JL, Canals M and Devincenzi M. 2005. A new high resolution tool to unveil the internal structure of deltaic sediment bodies based on geotechnical measurements (A case on the Llobregat delta plain, Barcelona) Open Science abstract, www.pages.unibe.ch.

CORRÊA JCS. 1995. Les variations du niveau de la mer durant les derniers 17.500 ans BP: l'exemple de la plateforme continentale du Rio Grande do Sul-Brésil. Mar Geol 130: 163-178.

Davies MP and Campanella RG. 1995. Piezocone Technology: Downhole Geophysics for the Geoenvironmental Characterization of soil. Proceedings. SAGEEP 95 Orlando, FL, USA, 11 p.

De Mio G, Giacheti HL, Ferreira FJF, Stevanato R AND GÓIS DE JR. 2005. Investigação de intrusão de água salgada em aquífero superficial a partir de medidas de resistividade elétrica. Solos e Rochas 28: 249-260.

Douglas BJ AND OLSEN RS. 1981. Soil Classification using electric cone penetrometer. Cone Penetration Testing and Experience. Proc. ASCE, St Louis, MO, USA, p. 209-227. 
Fellenius BH and Eslami A. 2000. Soil Profile Interpreted from CPTU data. Year 2000 Geotechnics Geotechnical Engineering Conference, Asian Institute of Technology, Bangkok, Thailand, $18 \mathrm{p}$.

Hegazy YA, Mayne PW and Rouhani S. 1991. Geostatistical assessment of spatial variability in piezocone tests. In: UNCERTAINTY IN THE GEOLOGIC ENVIRONMENT: From Theory to Practice, Proceedings of UNCERTAINTY '96. SHACKELFORD CD, NELSON PP AND Roth MJS (Eds), ASCE Geotech Spec Publ, New York, USA 58: 254-268.

Lessa G And Angulo RJ. 1995. A proposed model for the stratigraphy and evolution of the Paranaguá coastal plain - Paraná, Brazil. V Congresso ABEQUA, XI Sedimentologia Costeira. Niterói, RJ, Brazil, p. 92-98.

Lunne T, Robertson PK And Powell JJM. 1997. Cone Penetration Testing. In: SPON E AND SPON FN (Eds), Geotechnical Practice, 312 p.

Martin L, Flexor JM, Vilas BoAs GS, Bittencourt ACSP AND GUIMARÃES MMM. 1979. Courbe de variation du niveau relatif de la mer au cours des 7,000 dernières années sur un secteur homogène du littoral brésilien (nord de Salvador). Proceedings of an International Symposium on Coastal Evolution in the Quaternary, São Paulo, SP, Brasil, p. 264-274.

Martin L, Suguio K And Flexor JM. 1993. Sea level fluctuation during Upper Quaternary and the geological evolution of Brasilian deltas (in portuguese). Bull IG-USP (Special Publication) 15: 186
Martin L, BitTencourt ACSP, Dominguez JML, FLEXOR JM AND SUGUIO K. 1998. Oscillations or not oscillations, that is the question: Comment on Angulo JR and Lessa CG "The Brazilian sea-level curves: a critical review with enphasis on the curves from Paranaguá and Cananéia regions" (Mar Geol 140: 141-166). Mar Geol 150: $179-187$.

Martin L, Dominguez JML AND BITTENCOURT ACSP. 2003. Fluctuating Holocene Sea Levels in Eastern and Southeastern Brazil: Evidence from Multiple Fossil and Geometric Indicators. J Coastal Res 19: 101-124.

MASSAD F. 1988. História geológica e propriedades dos solos das baixadas. Dep Quatern Baix Litor. Rio de Janeiro, RJ, Brasil 1: 3.1-3.33.

MAssad F, SUguio K AND PÉREZ FS. 1996. Geotechnical properties of clay sediments as evidences of the relative sea water level fluctuations in Santos. (in Portuguese). 8 CBGE, Rio de Janeiro, RJ, Brazil 1: 163-177.

Robertson PK, Campanella RG, Gillespie D AND GREIG J. 1986. Use of piezometer cone data, Proceedings. In-Situ' 86 ASCE Specialty Conference on Use of In Situ Tests and Geotechnical Engineering. Virginia Polytecnic Institute, Blacksburg, VA, USA, p. 1263-1280. 